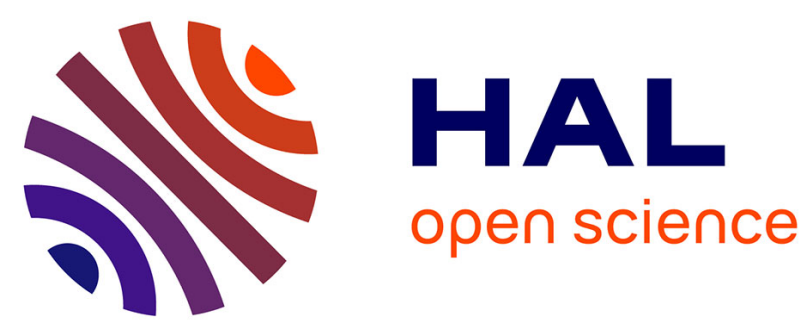

\title{
Theoretical analysis of the "green" synthesis of aniline by reduction of nitrobenzene
}

Qi Liu, Sarra Tadrent, Christophe Proust, François Gomez, Anissa Khelfa, Denis Luart, Christophe Len

\section{- To cite this version:}

Qi Liu, Sarra Tadrent, Christophe Proust, François Gomez, Anissa Khelfa, et al.. Theoretical analysis of the "green" synthesis of aniline by reduction of nitrobenzene. Chemical Engineering Science, 2020, 211, pp.art. 115275. 10.1016/j.ces.2019.115275 . ineris-03318112

\section{HAL Id: ineris-03318112}

\section{https://hal-ineris.archives-ouvertes.fr/ineris-03318112}

Submitted on 21 Dec 2021

HAL is a multi-disciplinary open access archive for the deposit and dissemination of scientific research documents, whether they are published or not. The documents may come from teaching and research institutions in France or abroad, or from public or private research centers.
L'archive ouverte pluridisciplinaire HAL, est destinée au dépôt et à la diffusion de documents scientifiques de niveau recherche, publiés ou non, émanant des établissements d'enseignement et de recherche français ou étrangers, des laboratoires publics ou privés.

\section{(ㄷ)(1) $\$$}

Distributed under a Creative Commons Attribution - NonCommerciall 4.0 International 


\title{
Theoretical analysis of the "green" synthesis of
}

\section{aniline by reduction of nitrobenzene}

Qi Liu, ${ }^{a}$ Sarra Tadrent, ${ }^{a}$ Christophe Proust,${ }^{a, b,{ }^{*}}$ Francois Gomez, ${ }^{a}$ Anissa Khelfa, ${ }^{c}$ Denis Luart, ${ }^{c}$ and

\author{
Christophe Len ${ }^{a, d}$
}

a Centre de Recherche Royallieu, Sorbonne Universités, Universite de Technologie de Compiegne, CS60319,

$$
\text { F-60203 Compiegne, France }
$$

b Dept DRA, parc Technologique Alata, INERIS, P.O Box 2, F-60550 Verneuil-en-Halatte, France

c Ecole Superieure de Chimie Organique et Minerale, 1 Rue du Reseau Jean-Marie Buckmaster, F-60200

$$
\text { Compiègne, France }
$$

d UMR 8247 CNRS Chimie ParisTech, PSL University, Institute of Chemistry for Life and Health Sciences, 11 Rue Pierre et Marie Curie, F-75005 Paris, France

\begin{abstract}
:
Recently a new chemical production means was proposed for producing aniline by reducing nitrobenzene in a much more environmentally friendly way (Tadrent et al., 2018). In particular, activated carbon and water are used instead of hydrogen on a metal catalyst without a precise detail of the process. In the present paper, a theoretical analysis is proposed based on a step by step thermodynamic examination of elementary reactions. It is found that the Haber mechanism is theoretically possible but that due to the size of the pores of the carbon, inside which the reduction occurs, only the smallest molecules can move so that the "direct" path is favored. This can explain
\end{abstract}


why the yield is rather good.

\section{Introduction:}

Aniline (AN) is an important chemical intermediate used for instance to synthesize polyurethane (Travis, 2007), The traditional way to produce AN is to reduce nitrobenzene (NB) to AN using hydrogen over a metal catalyst can produce a $100 \%$ selectivity towards AN at high pressure and temperature between 100 and $200^{\circ} \mathrm{C}$ (Couto et al., 2015), the process is particularly selective and efficient (about 67\% yield) (Varkolu et al., 2016; Wisniak et al., 1984). 100 Years ago, Haber(Haber, 1898) proposed a reaction pathway (Figure 1) for the reduction of NB according to which the "direct three steps" reduction of the NB molecule is competes a "condensation/reduction" route implying larger molecules. 


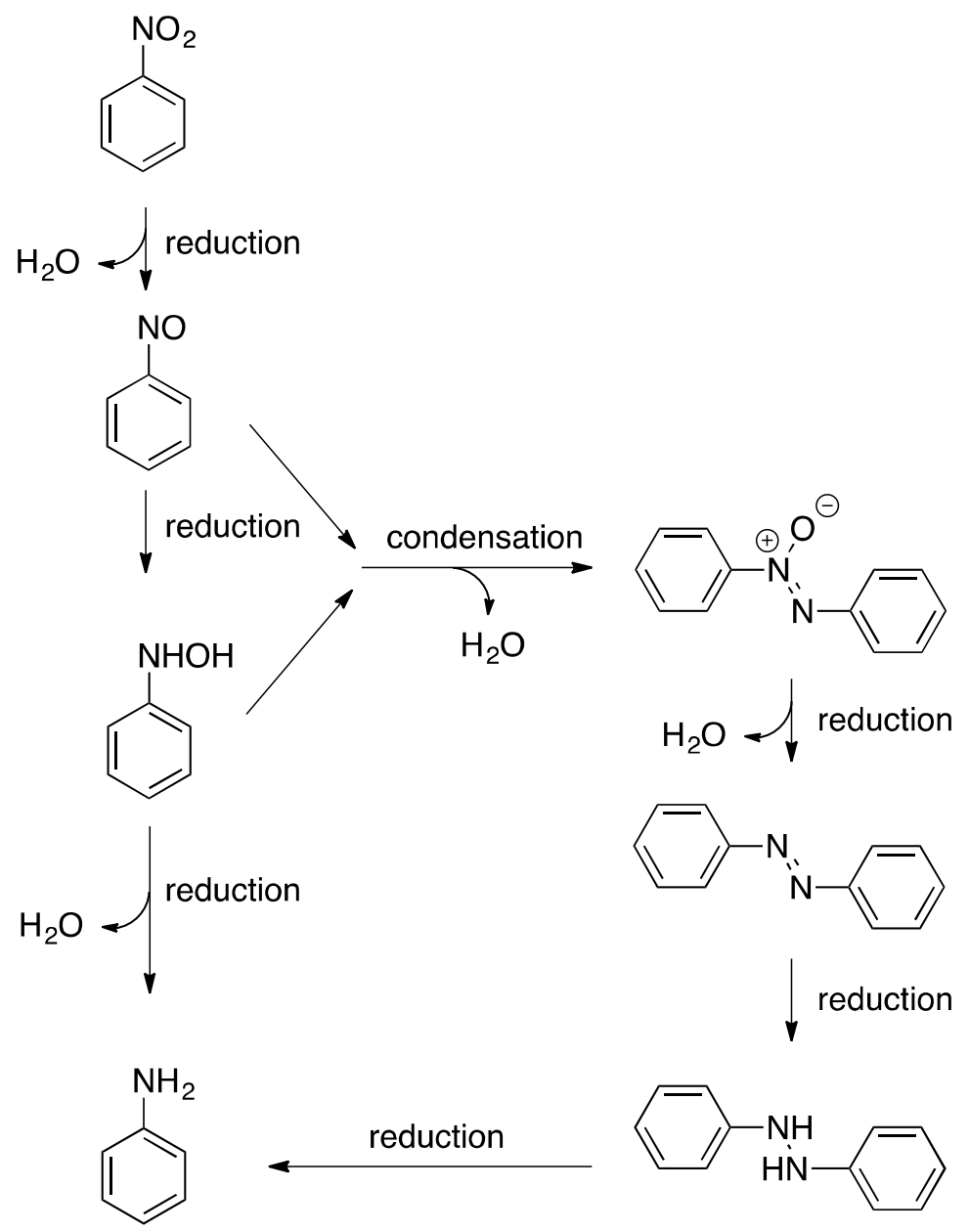

Figure 1. Potential reaction scheme for the reduction of nitrobenzene to aniline according to Haber.

Note that the traditional production route raises serious safety and environmental concerns. NB and hydrogen can produce very severe explosions (Tong, 1978) and AN is toxic (Gheewala et al., 1997), which would increase the accident consequence in case of a primary explosion of the reactor. The presence of metal in the products of the reaction is also to be avoided because of environmental concerns.

In this regard, the scientific community looks for an alternative process for the hydrogenation of 
nitro compounds in which hydrogen is produced in situ by a water-gas shift reaction (WGSR). Hydrogen is produced by the conversion of a mixture of carbon monoxide and water vapor into a mixture of carbon dioxide and hydrogen. Hydrogen is then continuously consumed by the NB. But this hydrogenation process still requires the use of metal catalysts (Pardey et al., 2000; Pardey et al., 2002; Sivcev et al., 2014). Recently, our group proposed and tested a new process successfully, also involving a WGSR without requiring the use of a catalyst (Tadrent et al., 2018). This new "green" chemical process is briefly recalled below with some typical results. But the details of the chemical reaction scheme were not clearly known and the present paper is an attempt to clarify this. To do this, a totally new "chemical equilibrium simulator", CIRCE, developed by the present team, is used which is described below also.

\section{Some Experimental Details}

The environmentally friendly approach for the reduction of NB to AN promoted by carbon catalyst was achieved successfully using activated carbon in water under subcritical water conditions. Hydrogen is generated and consumed in situ, and the synthesis temperature needed is lower $\left(300{ }^{\circ} \mathrm{C}\right.$ under 90 bars), which limits the risk of explosion. Furthermore, there is no need to use a catalyst. 


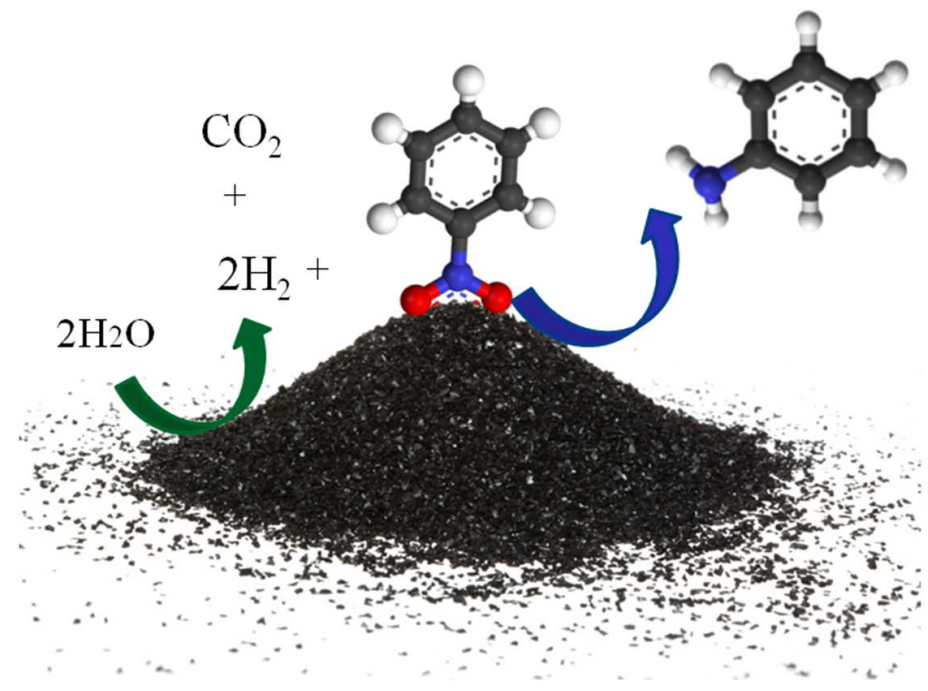

Figure 2. The proposed "green" process for the metal-free reduction of nitrobenzene to aniline on activated carbon /subcritical water substrate.

Only some representative results of the experimental work were selected. A $10 \mathrm{mmol}$ of NB $(1.23 \mathrm{~g})$ was dissolved in $55 \mathrm{~mL}$ (55 g, 3 moles) of water and mixed with $6 \mathrm{~g}$ of carbon. This "carbon" is charcoal either activated or not. For the present study, "untreated carbon" under the form of graphite powder "chemically" activated carbon Dacarb PC1000 and "physically" activated carbon Norit Gac 12-40 were used under the form of powders with a particle size on the order of $50 \mu \mathrm{m}$. One of the main features of activated carbon is porosity. The graphite powder is not porous and its specific surface is that of the particle (about $30 \mathrm{~m}^{2} / \mathrm{g}$ ). Activated carbons are intrinsically porous (Figure 3) with a specific surface of about $900 \mathrm{~m}^{2} / \mathrm{g}$ for Dacarb PC 1000 and Norit Gac 12-40. Pores usually characterized by their diameter: micro $<2 \mathrm{~nm}$, meso $2-50 \mathrm{~nm}$ and macropores $>50 \mathrm{~nm}$. For Dacarb and Norit, most (90\%) of the porosity is meso and micro. 


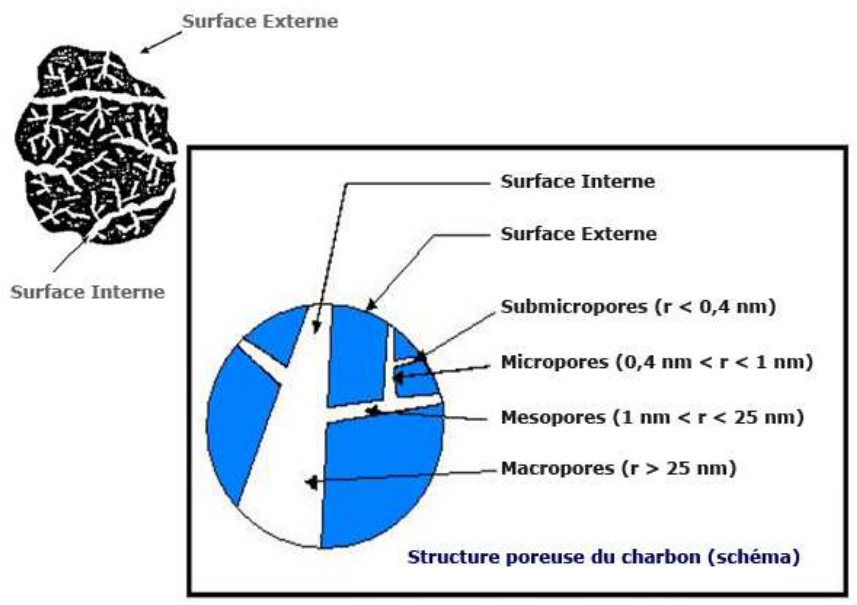

Figure 3. The structure of active carbon.

The experiments were performed in a discontinuous $100 \mathrm{~mL}$ stirred stainless steel (Parr 316) reactor (Figure 4) electrically heated using an external heating ribbon controlled by a temperature sensor. The pressure measured during the reaction is the autogenous pressure of the solution at the reaction temperature (about 90 bar between 280 to $320^{\circ} \mathrm{C}$ ) for 6 hours. The temperature in the autoclave was measured by a temperature probe.

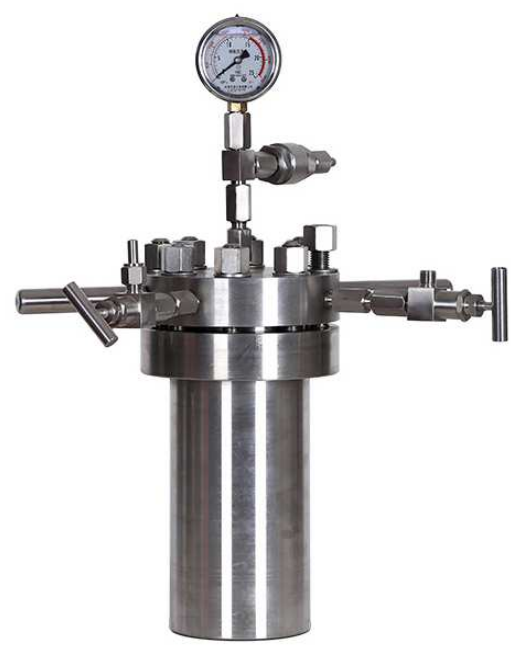

Figure 4. Type of autoclave used to perform the experiments. 
At the end of the reaction, the autoclave is cooled down to $40{ }^{\circ} \mathrm{C}$. The condensates are extracted and analyzed. All experiments were repeated at least three times and the scattering (in the compositions) was less than 5\%. Two parameters are considered hereafter : the "progress" of the reaction which is the number of reacted moles of NB divided by the initial number of moles of NB (in \%) and the "yield" of the reaction which is the number of moles of AN divided by the initial number of moles of NB (in \% also named conversion rate of NB into AN).

A parametric investigation was performed and in particular the influence of the temperature. The influence of the reaction temperature on the rates is shown in Table $\mathbf{1}$ for Norit activated carbon. It is observed that the yield increases with the temperature and to reach a maximum of $63 \%$ at $310^{\circ} \mathrm{C}$. About the influence of the nature of the carbon, graphite is clearly less efficient (Table 2).

Table 1. Influence of the reaction temperature (1.23 g nitrobenzene, $55 \mathrm{~g}$ water, $6 \mathrm{~g}$ Norit Gac 1240).

\begin{tabular}{|c|c|c|c|}
\hline Entry & $\mathrm{T}\left({ }^{\circ} \mathrm{C}\right)$ & Yield. (\%) & Progress. (\%) \\
\hline 1 & 275 & 33 & 82 \\
\hline 2 & 300 & 62 & 100 \\
\hline 3 & 310 & 66 & 100 \\
\hline 4 & 320 & 53 & 100 \\
\hline
\end{tabular}

Table 2. Influence of the nature of the carbon source $(6 \mathrm{~g}$ carbon, $1.23 \mathrm{~g}$ nitrobenzene, $55 \mathrm{~g}$ water, $\left.310^{\circ} \mathrm{C}\right)$.

\begin{tabular}{|c|c|c|c|}
\hline Entry & Carbon materials & Yield (\%) & Progress (\%) \\
\hline 1 & Graphite & 35,5 & 100 \\
\hline
\end{tabular}




\begin{tabular}{|c|c|c|c|}
\hline 2 & Norit Gac 12-40 & 62 & 100 \\
\hline 3 & Dacarb Pc1000 & 64 & 100 \\
\hline
\end{tabular}

\section{Some details about the theoretical tools and methods}

It was shown during the experiments that the equilibrium was reached. The idea is to use the theories of the thermodynamic equilibria to investigate what could have happened in the chemical process. The process is particularly complex, involving several reactions, several phases and many products. Gibbs showed that whatever the complexity, the final thermodynamic equilibrium is reached when the Gibbs energy of the system is minimum (Gibbs, 1948). Some software (Gordon and McBride, 1994; Liu et al., submitted in 2019; Plus, 2009) were developed to solve this sort of "Gibbs problem". We have shown elsewhere that they usually fail when 3 phases are present (Liu et al., 2019, submitted in 2019).

Because of this, our team developed a new software, CIRCE, able to deal with such very complex situations. The code is described elsewhere (Liu et al., 2018). The group theory of UNIFAC (Fredenslund et al., 1977) and the LCVM (Boukouvalas et al., 1994) equation of state are used to implement as accurately as possible the influence of the non-idealities (activity coefficients, compressibility...). The code can be used to find the thermodynamic equilibrium in various conditions, at constant temperature and pressure as done hereafter, but also in a variety of adiabatic conditions. It can also be used to calculate the evolution of the Gibbs energy of a given reaction $\Delta G_{\text {reaction }}(P, T)$ as a function of $\mathrm{T}$ or $\mathrm{P}$ :

$$
\text { a. } \mathrm{A} \rightarrow>\text { b. } \mathrm{B}+\text { c. } \mathrm{C}
$$

where A, B C are chemicals products and a, b, c the stoichiometric molar ratios.

$$
\Delta G_{\text {reaction }}=c \cdot G_{c}(P, T)+b \cdot G_{b}(P, T)-a \cdot G_{a}(P, T)
$$


When $\mathrm{P}$ and $\mathrm{T}$ are such that the Gibbs energy of the reaction is positive, the reaction cannot proceed. where $G_{a}(P, T)$ are chemical potentials of product 'a'.

\section{Thermodynamic analysis}

This analysis is conducted in two steps. In the first one, the thermodynamics of each potential elementary reaction is investigated thermodynamically, and in the second step, the Gibbs energy of the reaction is minimized taking into account of only the products likely to appear.

\section{Elementary reactions}

Qi and al. (Liu et al., submitted in 2018) developed a simple method to identify, which reaction is possible as a function of the T, P conditions. To summarize this method, CIRCE can propose the list of all the potential stable products, which could be formed based on the atomic composition of the reactant. Note that radicals do not appear "naturally". In the present situation, radicals where ignored. Based on this product database, the balanced reaction can be built, starting from the raw molecules. The process is continued with the molecules resulting from this first step up to the smallest.

Cyclic compounds are known to be very stable and difficult to decompose at low temperature. In particular, aromatic compounds, in which all ring atoms participate in a network of bonds, present an unusual stability. For instance, the thermal decomposition of benzene has been shown by Zanetti and al. (Zanetti and Egloff, 1917) to start at $500{ }^{\circ} \mathrm{C}$. NB start to decompose at $356{ }^{\circ} \mathrm{C}$ (Condit and Haynor, 1949). Nevertheless, NB is very stable and can only generate into benzenebased compounds (Matveev and Nazin, 1975). The possibility to condensate 2 aromatic cores was given to test this chemical route for producing AN. On these bases, from the list of potential products proposed by CIRCE only the following ones remain: $\mathrm{H}_{2}, \mathrm{O}_{2}, \mathrm{~N}_{2}, \mathrm{CO}, \mathrm{CO}_{2}, \mathrm{C}_{6} \mathrm{H}_{7} \mathrm{~N}$, 
$\mathrm{C}_{6} \mathrm{H}_{7} \mathrm{NO}, \mathrm{C}_{6} \mathrm{H}_{5} \mathrm{NO}_{2}, \mathrm{C}_{6} \mathrm{H}_{5} \mathrm{NO}, \mathrm{C}_{12} \mathrm{H}_{10} \mathrm{~N}_{2}, \mathrm{C}_{12} \mathrm{H}_{10} \mathrm{~N}_{2} \mathrm{O}, \mathrm{H}_{2} \mathrm{O}, \mathrm{C}_{6} \mathrm{H}_{7} \mathrm{~N}, \mathrm{C}_{6} \mathrm{H}_{7} \mathrm{NO}, \mathrm{C}_{6} \mathrm{H}_{5} \mathrm{NO}, \mathrm{C}_{12} \mathrm{H}_{10} \mathrm{~N}_{2}$, $\mathrm{C}_{12} \mathrm{H}_{10} \mathrm{~N}_{2} \mathrm{O}$, C. Starting from the raw compounds, the first elementary reactions are:

$$
\begin{gathered}
\mathrm{C}+\mathrm{H}_{2} \mathrm{O} \rightarrow \mathrm{CO}+\mathrm{H}_{2} \\
\mathrm{CO}+\mathrm{H}_{2} \mathrm{O} \rightarrow \mathrm{CO}_{2}+\mathrm{H}_{2} \\
\mathrm{C}_{6} \mathrm{H}_{5} \mathrm{NO}_{2}+\mathrm{H}_{2} \rightarrow \mathrm{C}_{6} \mathrm{H}_{5} \mathrm{NO}+\mathrm{H}_{2} \mathrm{O} \\
\mathrm{C}_{6} \mathrm{H}_{5} \mathrm{NO}_{2}+\mathrm{H}_{2} \mathrm{O} \rightarrow \mathrm{C}_{6} \mathrm{H}_{6}+\mathrm{HNO}_{3} \\
\mathrm{C}_{6} \mathrm{H}_{5} \mathrm{NO}_{2}+\mathrm{H}_{2} \rightarrow \mathrm{C}_{6} \mathrm{H}_{7} \mathrm{~N}+\mathrm{O}_{2} \\
\mathrm{C}_{6} \mathrm{H}_{5} \mathrm{NO}_{2}+\mathrm{H}_{2} \mathrm{O} \rightarrow \mathrm{C}_{6} \mathrm{H}_{6} \mathrm{O}+\mathrm{HNO}_{2}
\end{gathered}
$$

The evolution of the Gibbs energy of all these reactions as a function of the temperature at 80 bars is shown in Figure 5. Those for which the Gibbs energy is positive are thermodynamically very limited in terms of yield, and among the thermodynamically favored reactions (negative Gibbs energy), those with the smaller Gibbs energy should typically dominate although this is not a sufficient condition (kinetics needs also be considered).

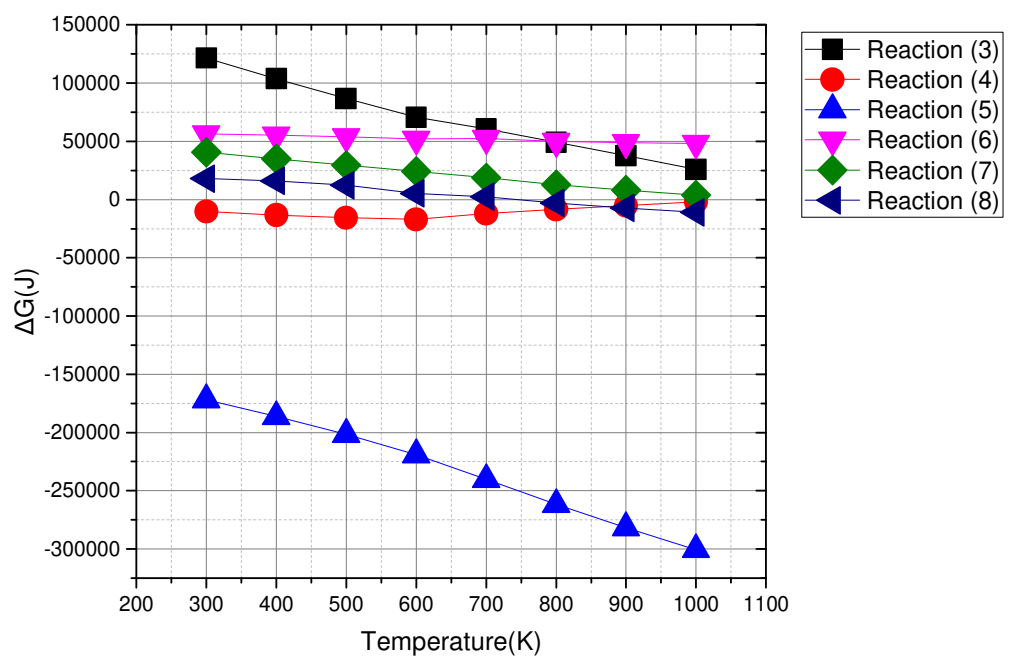


Figure 5. Gibbs energy as a function of the temperature for reactions (3) to (8) (calculated using CIRCE code under 80 bar pressure).

Consider first the hydrogenation reactions of NB (reactions 5 to 8). Clearly, reactions (5) is strongly favored so that the others would be hardly perceptible. Consider now the production of hydrogen which, in the context of the present experiments, is supposed to proceed from an oxidation of C by water (reactions (3) and (4)). Unfortunately, reaction (3) has got a positive Gibbs energy in the targeted temperature domain so that only very small quantities can be produced. But reaction (4) has a negative Gibbs energy so that the imbrication of both reactions may be able to produce enough hydrogen for the reduction of NB. This point was investigated separately simulating (using CIRCE) this water gas shift reaction (reactions (3) and (4)) in the present experimental conditions but without considering the presence of NB and associated compounds. Only reactions (3) and (4) are thus considered. The results are presented in Figure 6. Note the whole range of pressure and temperature is presented since, in the experiments, the reactive mixture is heated from ambient to about $600 \mathrm{~K}$ is a closed reactor so that both the temperature and the pressure vary. The ordinate is the total number of moles of hydrogen produced. Remember that only 0.01 mole of NB is available. According to the Haber reaction mechanism, 3 moles of hydrogen are required to transform 1 mole of NB into 1 mole of AN. So, in the present context, only 0.03 mole of $\mathrm{H}_{2}$ is enough. Clearly, reactions (3) and (4) have the thermodynamic capability of producing enough $\mathrm{H}_{2}$ provided enough time is left for the reaction to proceed. 


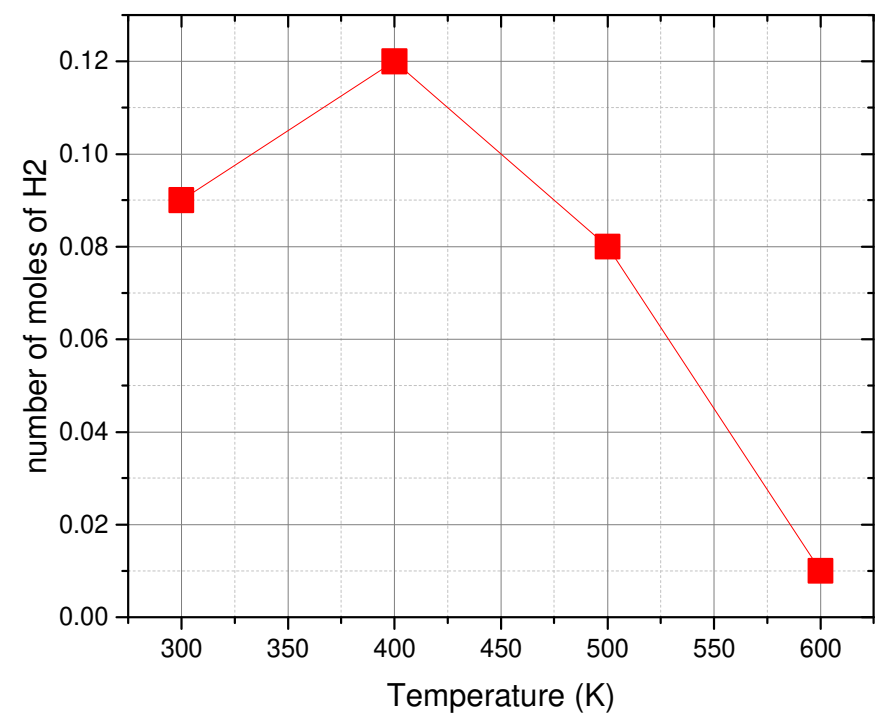

Figure 6. Calculated evolution of the maximum number of $\mathrm{H}_{2}$ moles produced during the heating up of the vessel (CIRCE code: $55 \mathrm{~g}$ water, $6 \mathrm{~g}$ carbon in a $100 \mathrm{ml}$ volume).

The next reaction steps are elaborated based on the products issued from the feasible reactions of the preceding steps.

The second step is:

$$
\begin{gathered}
\mathrm{C}_{6} \mathrm{H}_{5} \mathrm{NO}+\mathrm{H}_{2} \rightarrow \mathrm{C}_{6} \mathrm{H}_{7} \mathrm{NO} \\
\mathrm{C}_{6} \mathrm{H}_{5} \mathrm{NO}+\mathrm{C}_{6} \mathrm{H}_{7} \mathrm{NO} \rightarrow \mathrm{C}_{12} \mathrm{H}_{10} \mathrm{~N}_{2} \mathrm{O}+\mathrm{H}_{2} \mathrm{O} \\
\mathrm{C}_{6} \mathrm{H}_{5} \mathrm{NO}+\mathrm{H}_{2} \mathrm{O} \rightarrow \mathrm{C}_{6} \mathrm{H}_{6}+\mathrm{HNO}_{2}
\end{gathered}
$$




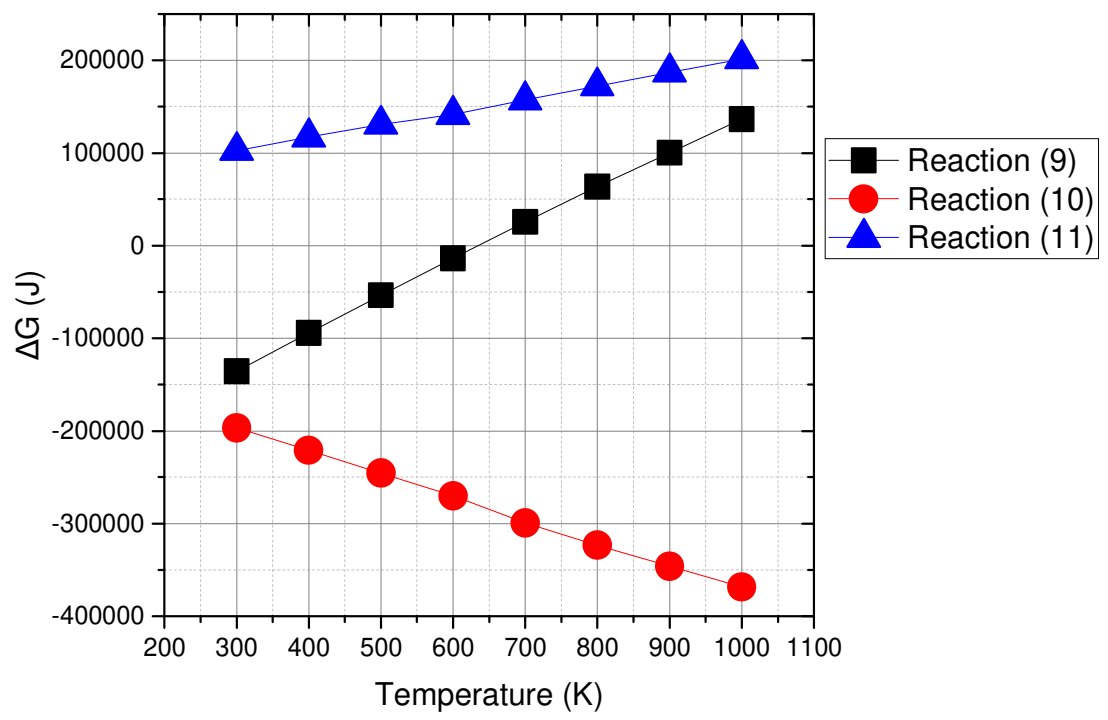

Figure 7. Gibbs energy as a function of the temperature for reactions (9) to (11) (atmospheric pressure-CIRCE code).

Reactions (9) and (10) are clearly favored but not reaction (11).

The third step would be:

$$
\begin{aligned}
& \mathrm{C}_{6} \mathrm{H}_{7} \mathrm{NO}+\mathrm{H}_{2} \rightarrow \mathrm{C}_{6} \mathrm{H}_{7} \mathrm{~N}+\mathrm{H}_{2} \mathrm{O} \\
& \mathrm{C}_{12} \mathrm{H}_{10} \mathrm{~N}_{2} \mathrm{O}+\mathrm{H}_{2} \rightarrow \mathrm{C}_{12} \mathrm{H}_{10} \mathrm{~N}_{2}+\mathrm{H}_{2} \mathrm{O}
\end{aligned}
$$




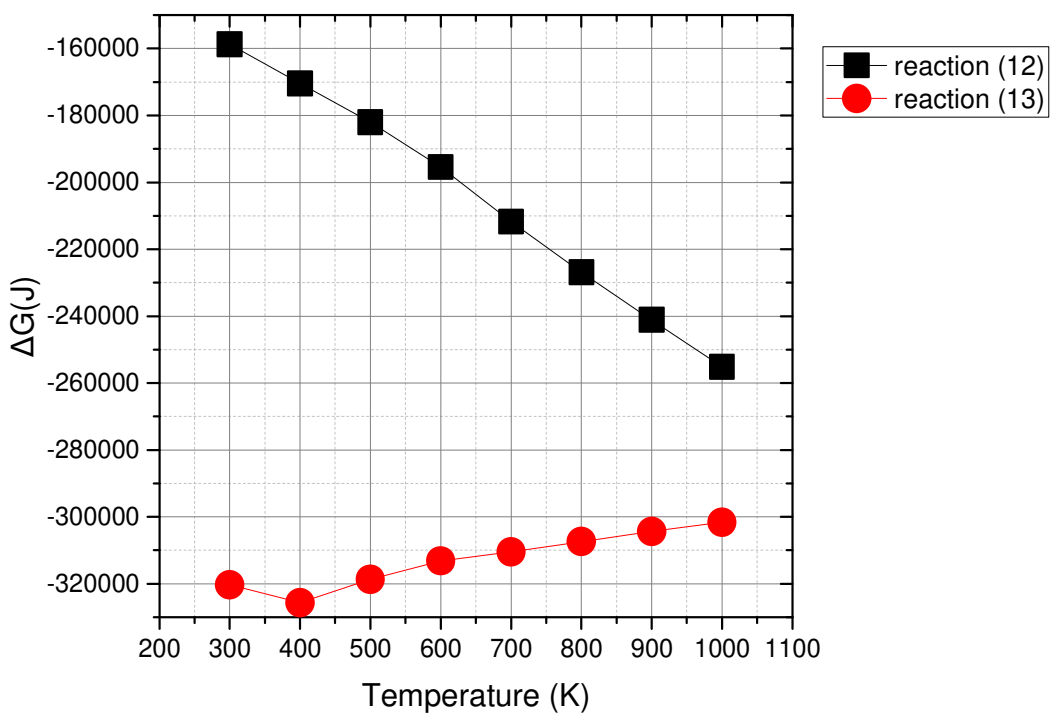

Figure 8. Gibbs energy as a function of the temperature for reactions (12) and (13) (atmospheric pressure-CIRCE code).

The reactions (12) and (13) are both favored.

The last step would be:

$$
\begin{aligned}
& \mathrm{C}_{12} \mathrm{H}_{10} \mathrm{~N}_{2}+\mathrm{H}_{2} \rightarrow \mathrm{C}_{12} \mathrm{H}_{12} \mathrm{~N}_{2} \\
& \mathrm{C}_{12} \mathrm{H}_{12} \mathrm{~N}_{2}+\mathrm{H}_{2} \rightarrow 2 \mathrm{C}_{6} \mathrm{H}_{7} \mathrm{~N}_{2}
\end{aligned}
$$




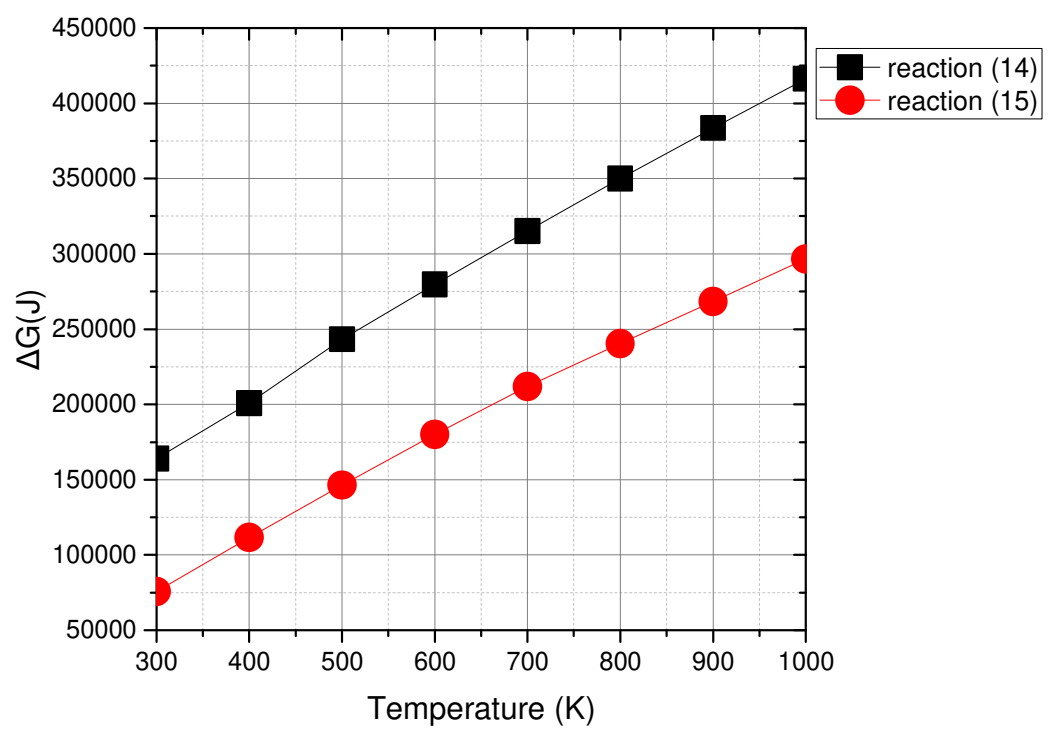

Figure 9. Gibbs energy as a function of the temperature for reactions (14) and (15) (atmospheric pressure-CIRCE code).

The reactions (14) and (15) are particularly unfavorable so that tiny quantities of AN can be expected from this reaction path. Since aromatic cycles are stable, no further reaction step is included. Following, the reaction scheme obtained this way is represented in Figure 10. 


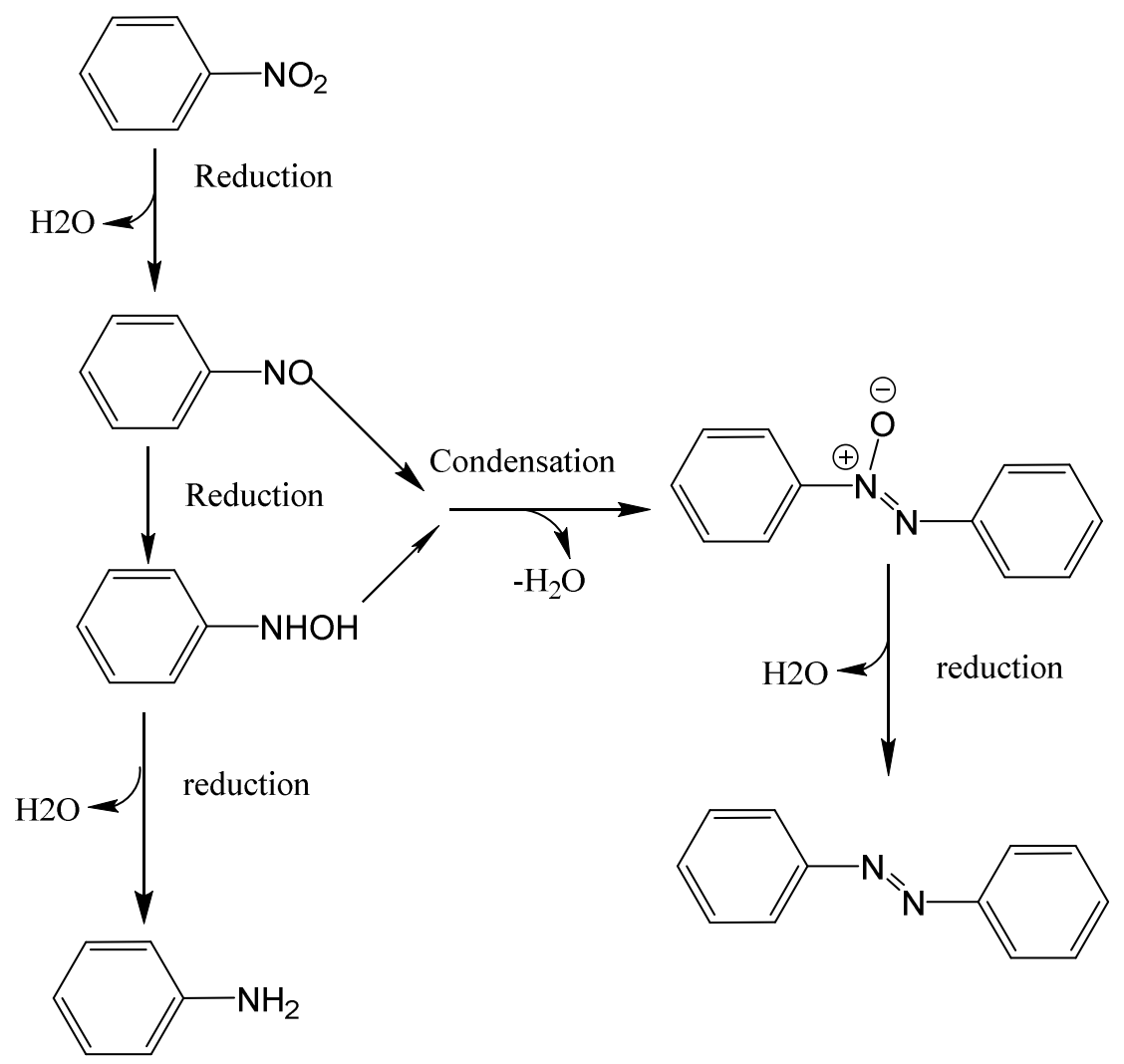

Figure 10. The revised potential scheme for the reduction of nitrobenzene into aniline.

This scheme only partly corroborates the Haber mechanism. The thermodynamic analysis suggests that $\mathrm{C}_{12} \mathrm{H}_{10} \mathrm{~N}_{2}$ cannot be easily reduced into $\mathrm{AN}$. $\mathrm{C}_{12} \mathrm{H}_{10} \mathrm{~N}_{2}$ appears as a byproduct.

\section{Simulating the chemical equilibrium}

To simulate the chemical equilibrium, an isothermal reaction implying $10 \mathrm{mmol}$ of NB (1.23 $\mathrm{g})$ dissolved in $55 \mathrm{~mL}$ (55 g, 3 moles) of water and mixed with $6 \mathrm{~g}$ of carbon in a constant $100 \mathrm{~mL}$ vessel is considered to mimic the experimental conditions. The reaction temperature is varied in the range of $250^{\circ} \mathrm{C}-300^{\circ} \mathrm{C}$. The calculation of thermodynamic equilibrium can be done with the CIRCE software. (Liu et al., submitted in 2019) From the preceding analysis, the selected final 
products are gases $\left(\mathrm{H}_{2} \mathrm{O}, \mathrm{H}_{2}, \mathrm{O}_{2}, \mathrm{CO}, \mathrm{CO}_{2}, \mathrm{C}_{6} \mathrm{H}_{7} \mathrm{~N}, \mathrm{C}_{6} \mathrm{H}_{7} \mathrm{NO}, \mathrm{C}_{6} \mathrm{H}_{5} \mathrm{NO}_{2}, \mathrm{C}_{6} \mathrm{H}_{5} \mathrm{NO}, \mathrm{C}_{12} \mathrm{H}_{10} \mathrm{~N}_{2} \mathrm{O}\right.$, $\left.\mathrm{C}_{12} \mathrm{H}_{10} \mathrm{~N}_{2}, \mathrm{C}_{12} \mathrm{H}_{12} \mathrm{~N}_{2}\right)$, liquids $\left(\mathrm{H}_{2} \mathrm{O}, \mathrm{C}_{6} \mathrm{H}_{7} \mathrm{~N}, \mathrm{C}_{6} \mathrm{H}_{7} \mathrm{NO}, \mathrm{C}_{6} \mathrm{H}_{5} \mathrm{NO}, \mathrm{C}_{12} \mathrm{H}_{10} \mathrm{~N}_{2} \mathrm{O}, \mathrm{C}_{12} \mathrm{H}_{10} \mathrm{~N}_{2}, \mathrm{C}_{12} \mathrm{H}_{12} \mathrm{~N}_{2}\right)$ and solid carbon (to mimic the char which contains more than $90 \% \mathrm{~m} / \mathrm{m}$ fixed carbon). Clearly, the simulation results look very different from the experimental results, although the list of products, as mentioned above, is reasonable (Figure 10).

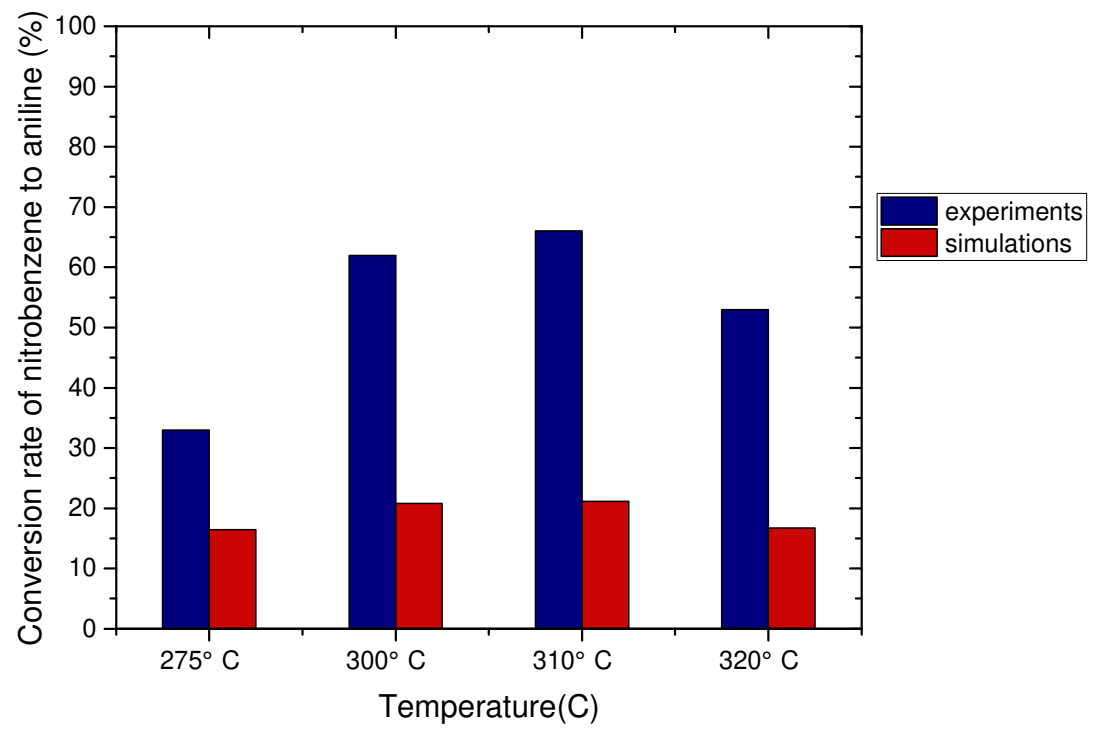

Figure 11. Comparison between the simulation results in red (obtained with CIRCE with all 13 products) and the experimental values in blue (Norit Gac 12-40 activated carbon).

It is known that chemical equilibrium calculations using the Gibbs method provide the best possible yield of a reactive medium. If experimental results are "better" than simulated, it means that products are lacking in the database or too much of them are present.

The second option is investigated here, remembering that activated carbons are porous.

The larger molecules such as $\mathrm{C}_{12} \mathrm{H}_{10} \mathrm{~N}_{2} \mathrm{O}$ are nanometers large so that they may hardly move or even be created in the micro-meso pores constituting most of the reactive surface of activated 
carbons. For this reason, it can be assumed that the direct reaction path would be favored $\left(\mathrm{C}_{6} \mathrm{H}_{5} \mathrm{NO}_{2}->\mathrm{C}_{6} \mathrm{H}_{5} \mathrm{NO}->\mathrm{C}_{6} \mathrm{H}_{7} \mathrm{NO}->\mathrm{C}_{6} \mathrm{H}_{7} \mathrm{~N}\right)$.

The simulations were reprocessed after removing all the $C_{12}$ molecules (Figure 10). The considered products are gases $\left(\mathrm{H}_{2} \mathrm{O}, \mathrm{H}_{2}, \mathrm{CO}, \mathrm{CO}_{2}, \mathrm{C}_{6} \mathrm{H}_{7} \mathrm{~N}, \mathrm{C}_{6} \mathrm{H}_{7} \mathrm{NO}, \mathrm{C}_{6} \mathrm{H}_{5} \mathrm{NO}_{2}, \mathrm{C}_{6} \mathrm{H}_{5} \mathrm{NO}\right)$, liquids $\left(\mathrm{H}_{2} \mathrm{O} \mathrm{C}_{6} \mathrm{H}_{7} \mathrm{~N}, \mathrm{C}_{6} \mathrm{H}_{7} \mathrm{NO}, \mathrm{C}_{6} \mathrm{H}_{5} \mathrm{NO}_{2}, \mathrm{C}_{6} \mathrm{H}_{5} \mathrm{NO}\right)$ and solid (C).

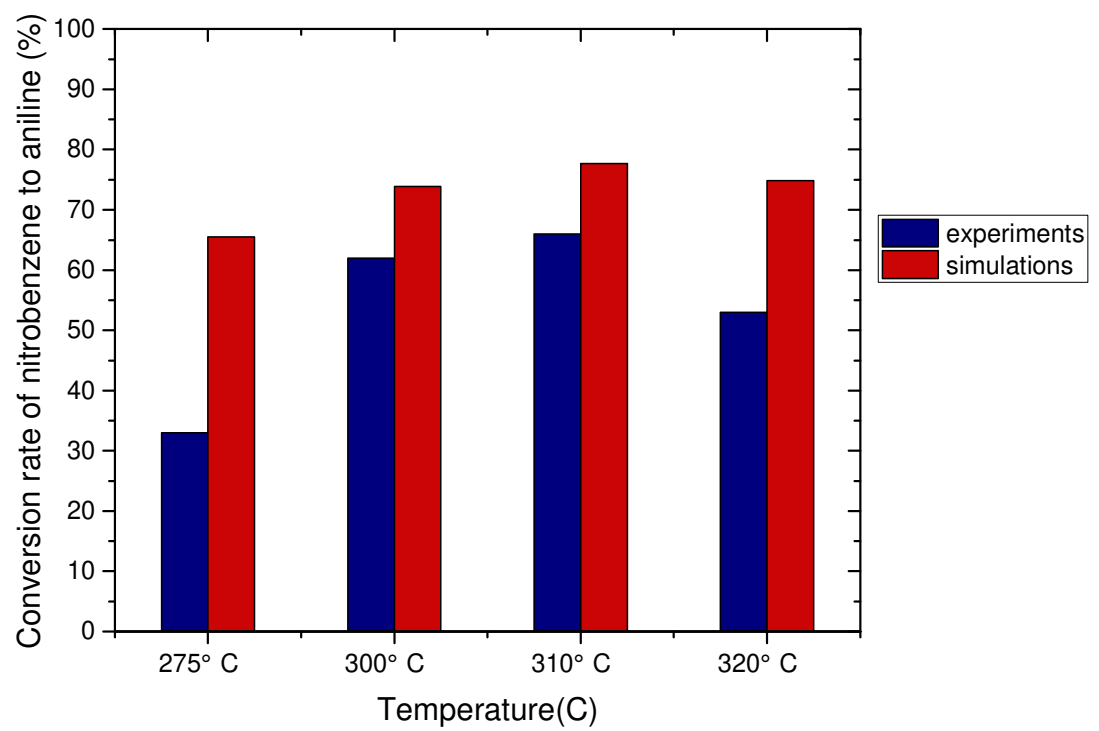

Figure 12. Comparison between the simulation results in red (obtained with CIRCE with the reduced product list) and the experimental values in blue (Norit Gac 12-40 activated carbon).

The simulation now corresponds much better to the experiments. The same yield would be obtained with the other kind of activated carbon since its topology is similar. The graphite case is particularly interesting. Graphite is not porous, and most of its active surface (mostly the outer surface of each particle) is readily accessible to the large C12 molecules. The maximum yield obtained in the same experimental conditions was only about $30 \%$, which is more in line with the results from Figure 11. 
All of this suggests that not only the possibility to reduce NB to AN in subcritical water with carbon is viable but also that the yield of the reaction is favored by the porous nature of the carbon. Obviously, other catalyst effects need to be accounted for (Blaser et al., 2009) but nevertheless, the diffusional/mechanical aspects of the reaction may explain a lot about the reaction.

\section{Conclusion}

The synthesis of AN by reducing NB is studied numerically, and the results are compared to experimental values in view of interpreting the results. The novelty of this synthesis path is that no added hydrogen, nor catalyst are used but the reduction is obtained using carbon and subcritical water. The latter reactants are supposed to produce hydrogen in situ, which is used to perform the reduction. Note that porous activated carbon is used.

To do the simulations, the in-house developed software CIRCE was used. CIRCE (LIU et al., submitted in 2018) is capable of providing the list of all products of a reaction (from the atomic composition of the reactants) and can calculate the multiphase chemical equilibrium.

The thermodynamic analysis or the elementary reactions suggests that the Haber reaction mechanism is only partly possible involving a direct path involving only $\mathrm{C}_{6}$ molecules and an indirect path involving $\mathrm{C}_{12}$ molecules. It is found that this second path is much less likely.

If both pathways are implemented, the calculated conversion rate of NB in AN is only about $30 \%$, which is much less than measured with activated carbons $(65 \%)$. Note this calculated yield is very much in line with the measurements when non-porous graphite is used instead of activated carbons. When the $\mathrm{C} 12$ molecules are withdrawn, the calculated yield is much closer to those measures with activated carbons. The interpretation is that large C12 molecule could hardly move inside the pores so that may not be produced or react. This would suggest that the mechanical 
aspect of the carbon is a very important aspect, and the present calculations helped to understand this.

\section{AUTHOR INFORMATION}

\section{Corresponding Author}

*E-mail: christophe.proust@ineris.fr

\section{Notes}

The authors declare no competing financial interest.

\section{Acknowledgment}

The authors thank the Ministère de l'Enseignement Supérieur et de la Recherche for its constant supports.

\section{References:}

Blaser, H. U., Steiner, H., Studer, M., 2009. Selective catalytic hydrogenation of functionalized nitroarenes: an update. ChemCatChem, 1, 210-221.

Boukouvalas, C., Spiliotis, N., Coutsikos, P., Tzouvaras, N., Tassios, D., 1994. Prediction of vapor-liquid equilibrium with the LCVM model: a linear combination of the Vidal and Michelsen mixing rules coupled with the original UNIF. Fluid Phase Equilib., 92, 75-106.

Condit, P., Haynor, R., 1949. Thermal Decomposition of Nitroxylene and Nitrobenzene. J. ind. Eng. Chem., 41, 1700-1704.

Couto, C.S., Madeira, L.M., Nunes, C.P., Araújo, P., 2015. Hydrogenation of nitrobenzene over a $\mathrm{Pd} / \mathrm{A} 12 \mathrm{O} 3$ catalyst-mechanism and effect of the main operating conditions. Chem. Eng. 
Technol., 38, 1625-1636.

Fredenslund, A., Gmehling, J., Michelsen, M.L., Rasmussen, P., Prausnitz, J.M., 1977.

Computerized design of multicomponent distillation columns using the UNIFAC group contribution method for calculation of activity coefficients. Ind. Eng. Chem. Process Des. Dev., 16, 450-462.

Gheewala, S.H., Annachhatre, A.P., 1997. Biodegradation of aniline. Water Sci. Technol., 36, 53-63.

Gibbs, J.W., 1948. The collected works of J. Willard Gibbs. Yale Univ. Press.

Gordon, S., McBride, B.J., 1994. Computer Program for Calculation of Complex Chemical Equilibrium Compositions and Applications. Part 1: Analysis.

Haber, F., 1898. Gradual electrolytic reduction of nitrobenzene with limited cathode potential. Elektrochem. Angew. Phys. Chem, 22, 506-514.

Liu, Q., Proust, C., Gomez, F., Luart, D., Len, C., 2018. Improving the predictability of chemical equilibrium software. Ind. Eng. Chem. Res., 58, 411-419.

LIU, Q., Proust, C., Gomez, F., Luart, D., Len, C., 2019. Sensitivity of the predictability of chemical equilibrium software to the choice of the products. Ind. Eng. Chem. Res..

Liu, Q., Proust, C., Gomez, F., Luart, D., Len, C., submitted in 2019. Predicting multi-phase chemical equilibria using a Monte Carlo technique. Geochim. Cosmochim. Acta.

Matveev, V., Nazin, G., 1975. Kinetics and mechanism of the decomposition of nitrobenzene in the gas phase. Bulletin of the Academy of Sciences of the USSR, Division of chemical science, 24, 697-700.

Pardey, A., Fernández, M., Alvarez, J., Urbina, C., Moronta, D., Leon, V., Longo, C., Baricelli, P., Moya, S., 2000. The reduction of nitrobenzene as catalyzed by poly (4-vinylpyridine)- 
immobilized [Rh (COD)(amine) 2](PF6) complexes under WGSR conditions. J. Mol. Catal. AChem., 164, 225-234.

Pardey, A.J., Fernández, M.a., Rivas, A.B., Ortega, M.C., Urbina, C., Moronta, D., Longo, C., Mediavilla, M., Baricelli, P.J., Moya, S.A., 2002. Water gas shift reaction and nitrobenzene reduction catalysis by tetracarbonyldi- $\mu$-chlorodirhodium (I) complex immobilized on poly (4vinylpyridine). Inorg. Chim. Acta, 329, 22-30.

Plus, Aspen, 2009. Aspen technology. Inc, version 11.

Sivcev, V., Korchagina, D., Suslov, E., Volcho, K., Salakhutdinov, N., Anikeev, V., 2014. Efficient reduction of nitroarenes using supercritical alcohols as a source of hydrogen in flowtype reactor in the presence of alumina. J. Supercrit. Fluid., 86, 137-144.

Tadrent, S., Luart, D., Bals, O., Khelfa, A., Luque, R., Len, C., 2018. Metal-free reduction of nitrobenzene to aniline in subcritical water. J. Org. Chem., 83, 7431-7437.

Tong, W.R., 1978. 3, 4-Dichloroaniline autoclave incident. Loss Prevention, 11, 71.

Travis, A. S., 2007. Manufacture and uses of the anilines: A vast array of processes and products. The chemistry of Anilines, 715-782.

Varkolu, M., Velpula, V., Pochamoni, R., Muppala, A.R., Burri, D.R., Kamaraju, S. R. R., 2016. Nitrobenzene hydrogenation over $\mathrm{Ni} / \mathrm{TiO}_{2}$ catalyst in vapour phase at atmospheric pressure: influence of preparation method. App. Pet. Res., 6, 15-23.

Wisniak, J., Klein, M., 1984. Reduction of nitrobenzene to aniline. Res. Dev., 23, 44-50.

Zanetti, J. E., Egloff, G., 1917. The Thermal Decomposition of Benzene. Ind. Eng. Chem., 9, $350-356$. 